\title{
Evaluation of biochemical parameters in calcium oxalate renal stone formers
}

\author{
Mannal Abd AL-Monim Ibrahim \\ College of Pharmacy, Department of Clinical Libratory Sciences /University of Mosul
}

\begin{abstract}
Received
Accepted

24.5.2012

4.12.2012

ABSTRACT
\end{abstract}

Background: Calcium oxalate renal stones are the most predominant cases of renal stones, their formation is more complex and no specific cause for the stone can be identified so called 'idiopathic'. This study was designed to analyze the metabolic and biochemical alterations in serum, urine and their relation to pathophysiology of calcium oxalate stone formation

Patients and Methods : In this study, individuals have been classified into three groups: Group (A) included (29) apparently healthy persons of non calcium oxalate stone formers aged (20-35 years), group (B) included (16) patients with calcium oxalate renal stone aged (20-35 years) and group(C) included (15) patients with calcium oxalate renal stone aged (40-70 years). Fasting serum, random urine and 24hours urine samples were collected from all individuals to determine urine volume, creatinine clearance, serum and urine levels of calcium, phosphate ,uric acid ,zinc, copper and serum levels of total cholesterol, high density lipoproprotien-cholesterol and urea .

Results: Calcium oxalate stone formers group (B) exhibited significantly decreased serum levels of uric acid $(P=0.015)$,zinc $(P=0.031)$ with increased serum level of total cholesterol $(P=0.034)$ when compared to similar age group of healthy control ,group (A). Urinary parameters in calcium oxalate stone formers also showed significantly increased levels of 24-hour urine calcium $(P=0.05)$ and urine calcium: creatinine ratio $(P=0.05)$ when compared to healthy control. While, older age calcium oxalate stone formers, group (C) showed significantly decreased urine volume $(P=0.015)$ with increased kidney stone $\operatorname{size}(P=0.03)$ when compared to younger age calcium oxalate stone formers, group (B).

Conclusions: Level of urinary calcium and urine volume are the most important urinary factors in enhancing calcium oxalate stone formation. While the observed changes in biochemical measurements of serum in calcium oxalate stone formers may indicate a probable metabolic relation in pathogenesis of this disease.

Key words : Nephrolithiasis , 24-hours urine collection, stone formers, Calcium oxalate

$$
\begin{aligned}
& \text { الخلاصة }
\end{aligned}
$$

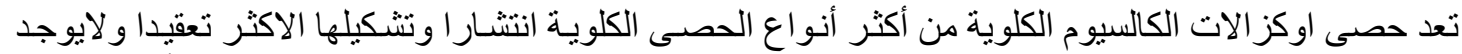

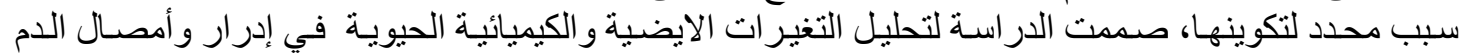

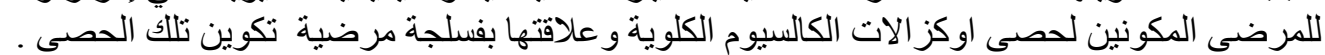

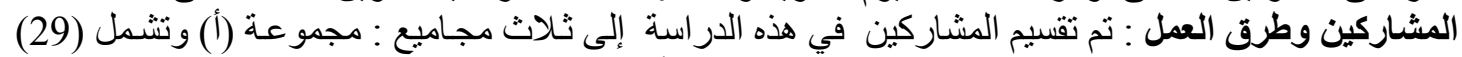

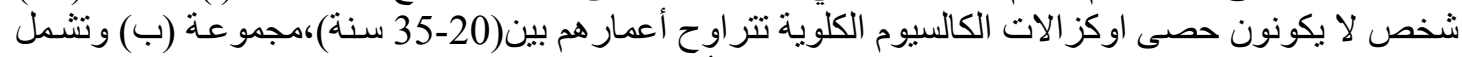

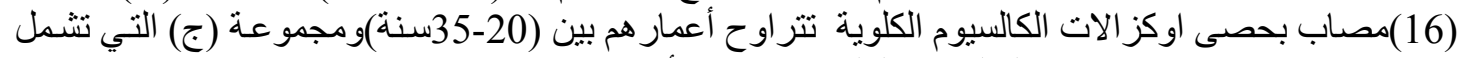

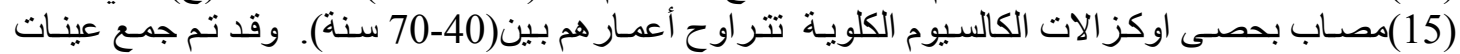

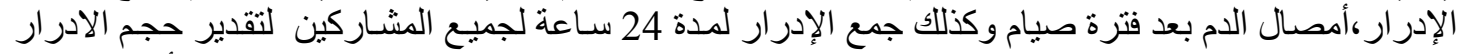

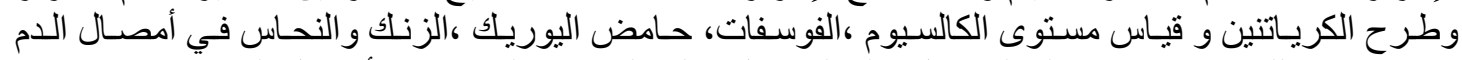

$$
\begin{aligned}
& \text { و الإدرار وكذلك تقدير مستوى الكولسترول و الكولسترول عالي الكثافة و اليوريا في أمصال الدام }
\end{aligned}
$$




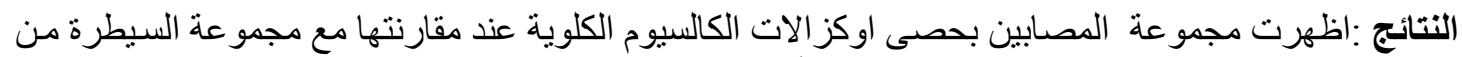

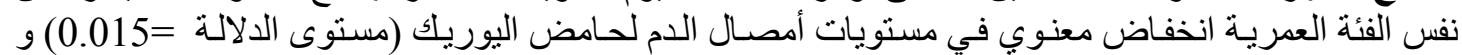

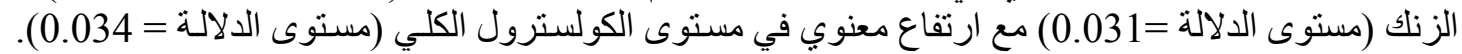

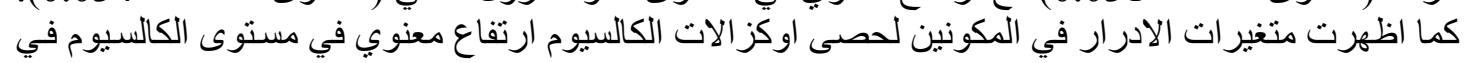

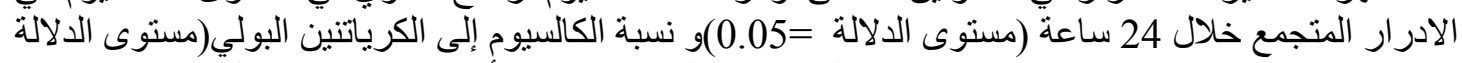

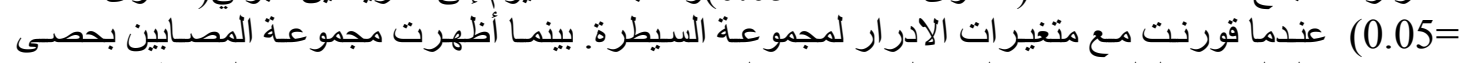

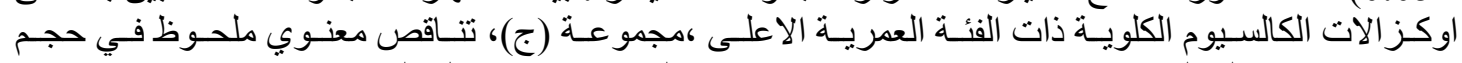

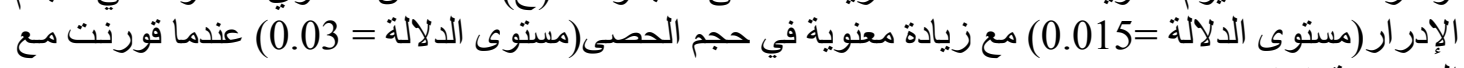

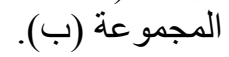

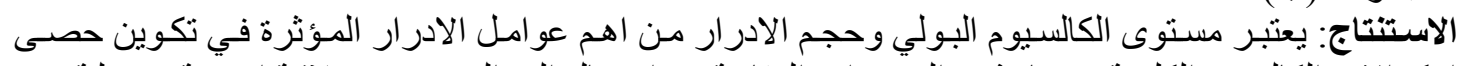

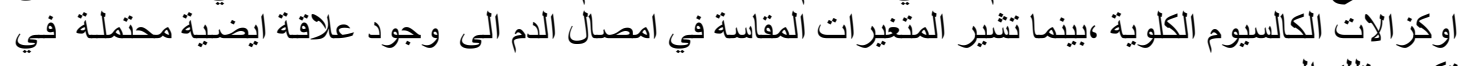
تكوين تللك الحصى.

$\mathbf{R}^{\mathrm{e}}$ enal stone formation is a common disease with increasing incidence and prevalence worldwide ${ }^{1}$. Climate, changing life style and dietary choices are the most probable causes of increasing incidence and prevalence $^{2}$.The annual incidence in Europe and North America is roughly of $0.5 \%$ with prevalence of $5.2 \%$ and $50 \%$ of patients may develop a new episode $^{3}$. However, data from some developing countries showed similar figures to those described in western countries ${ }^{4}$.

Different studies related the renal stone formation to different metabolic disturbances. Pack et al (2004) proposed that serious changes in urinary factors may lead to formation of kidney stone ${ }^{5}$. Also, Maghbooli et al (2007) study exhibited a strong association between renal stone and metabolic bone disease ${ }^{6}$, while Mossetti et al (2008) study showed that metabolic syndrome and nephrolithiasis have a common background ${ }^{7}$.

According to chemical composition, renal stones can be classified into different types. Calcium oxalate renal stone is the most predominant type of renal stones in Iraq and different part of the world representing about $75 \%$ of cases. ${ }^{4,8,9}$ The formation of calcium oxalate stones is more complex and not yet completely understood and in most cases no specific cause for the stone formation can be identified and so called 'idiopathic'. ${ }^{10}$

Most studies on renal stone didn't specify type or size of the stone. The present study included idiopathic calcium oxalate stone formers of relatively small size stone to analyze biochemical and metabolic alterations that affecting the pathophysiology of renal stone, and excluding the relatively harmful mechanical effects or kidney damage produced by other types of stones or relatively larger stones.

The aim of the present study was to investigate the possible metabolic changes that could be associated with idiopathic calcium oxalate renal stone formation.

\section{Patients and Methods}

Sixty individuals shared in this study during the period from April /2011 to December /2011. The individuals were divided into three groups: Group A (control) included (29) apparently healthy individuals without renal stone aged (20-35years), while group B and group C were of renal stone formers, who attended ALJamhuri Teaching Hospital/Center of Extracorporeal Shock Wave Lithotripsy. Group B involved(16)renal stone formers aged (20-35years)and group $\mathrm{C}$ involved (15) renal stone formers aged (40-70 years).

The detection of calcium oxalate stone is confirmed by patient history 
,ultrasound, and radio image, all stones seems to be located in left and/ or right kidney with stone size of less than 15 $\mathrm{mm}^{3}$. Patients with acute or chronic kidney disease, Diabetes Mellitus, hypertension or patients on thiazide diuretics, calcium supplements were excluded from the study.

Sample collections and measurements: Random urine samples were taken to test for: types of crystals, presence of protein (individuals with no urinary protein were included). Concerning group B and group C, only those exhibited urinary calcium oxalate crystals were included that confirm radiological testing and previous patient history. ${ }^{11,12}$ The selected individuals agree to do fasting blood collection and 24- hours urine collection to measure serum and urine levels of calcium, phosphate, uric acid, creatinine, zinc and copper in addition to serum levels of total cholesterol, HDL-C and urea. Calcium was determined according to O-Cresol Phthalin Complexone (CPC) method using kit manufactured by Biolabo (France), phosphate was determined by reaction with ammonium molybdate in acidic medium a method without deproteinisation using kit manufactured by Biolabo (France), uric acid was determined by uricase method using Biolabo kit (France), creatinine was determined by Jaffe's reaction and measured kinetically using Biolabo kit (France). Whereas, zinc and copper were determined by Shimadzu AA 670 spectrophotometer using atomic absorption technique, the absorbance measurement of zinc was at $213.9 \mathrm{~nm}$ wavelength and copper at $324.8 \mathrm{~nm}$, cholesterol was measured by enzymatic method using Biolabo kit (France), HDL-c was determined by separation of HDL from serum then determination of cholesterol present in HDL by enzymatic method using kit purchased by Biolabo (France) and urea was measured by enzymatic colorimetric method using Biolabo kit (France).

The research protocol for this study was reviewed and approved by Scientific Committee of Department of Pharmacology/College of PharmacyMosul and the Research Committee of Ninavaha Health Directorate. All patients were informed about the research study .

Statistical analysis: The variables were evaluated for statistical significance by chi-square and t-test, the differences are considered to be statistically significant if $P \leq 0.05$. The analysis was performed with the statistical package SPSS collection (version 16).

\section{Results}

Group (A) was compared to group (B) to show the differences between normal healthy individuals and those with renal stones, also group (B) was compared to group (c) to show the effect of age on stone formation; as both of them, group (B) and (C), consist of renal stone formers but of different age groups. 
Table 1. A Comparative description of healthy control and calcium oxalate stone formers(group A and group B) and a comparative description of calcium oxalate stone formers of different ages(group B and group C)

\begin{tabular}{|l|l|l|l|l|l|l|}
\hline Parameters & $\begin{array}{l}\text { Group A } \\
(\mathrm{n}=29)\end{array}$ & $\begin{array}{l}\text { Group B } \\
(\mathrm{n}=16)\end{array}$ & $p$-value & $\begin{array}{l}\text { Group B } \\
(\mathrm{n}=16)\end{array}$ & $\begin{array}{l}\text { Group C } \\
(\mathrm{n}=15)\end{array}$ & $p$-value \\
\hline Age(years) & $26.1 \pm 6.3$ & $28.1 \pm 3.89$ & NS & $28.1 \pm 3.89$ & $54.1 \pm 8.86$ & $\mathbf{0 . 0 0} * *$ \\
\hline $\begin{array}{l}\text { Percentage of } \\
\text { eating red meat }\end{array}$ & $90 \%$ & $85 \%$ & NS & $85 \%$ & $83 \%$ & NS \\
\hline $\begin{array}{l}\text { Percentage of } \\
\text { drinking beverage }\end{array}$ & $60 \%$ & $42 \%$ & NS & $42 \%$ & $58 \%$ & NS \\
\hline $\begin{array}{l}\text { Mean of stone } \\
\text { size }\left(\mathrm{mm}^{3}\right)\end{array}$ & \multicolumn{7}{|l|}{} & & $6.78 \pm 2.48$ & $10.14 \pm 3.4$ & $\mathbf{0 . 0 3 *}$ \\
\hline
\end{tabular}

Parametric data represented as mean $\pm \mathrm{SD}$, non-parametric data represented as percentage

$\mathrm{NS}=($ not significant $) p$ value $\geq 0.05, *$ significant difference $(p$ value $\leq 0.05), * *$ significant difference $(p$ value $\leq$ $0.005)$

Table 2. Some serum biochemical measurements of healthy control (group A), calcium oxalate stone formers(group B )and calcium oxalate stone formers (group C ) represented as mean \pm SD

\begin{tabular}{|l|c|c|c|c|c|c|}
\hline \multicolumn{1}{|c|}{$\begin{array}{c}\text { Biochemical } \\
\text { Parameters }\end{array}$} & $\begin{array}{c}\text { Group A } \\
(\mathrm{n}=29)\end{array}$ & $\begin{array}{c}\text { Group B } \\
(\mathrm{n}=16)\end{array}$ & $\begin{array}{c}p- \\
\text { value }\end{array}$ & $\begin{array}{c}\text { Group B } \\
(\mathrm{n}=16)\end{array}$ & $\begin{array}{c}\text { Group C } \\
(\mathrm{n}=15)\end{array}$ & $\begin{array}{c}p- \\
\text { value }\end{array}$ \\
\hline $\begin{array}{l}\text { Calcium } \\
(\mathrm{mmol} / \mathrm{L})\end{array}$ & $2.28 \pm 0.267$ & $2.2 \pm 0.267$ & $\mathrm{NS}$ & $2.2 \pm 0.267$ & $2 \pm 0.40$ & $\mathrm{NS}$ \\
\hline $\begin{array}{l}\text { Phosphate } \\
(\mathrm{mmol} / \mathrm{L})\end{array}$ & $1.067 \pm 0.36$ & $0.944 \pm 0.13$ & $\mathrm{NS}$ & $0.944 \pm 0.13$ & $1.215 \pm 0.6$ & $\mathrm{NS}$ \\
\hline $\begin{array}{l}\text { Uric acid } \\
(\mathrm{mmol} / \mathrm{L})\end{array}$ & $0.33 \pm 0.092$ & $0.28 \pm 0.052$ & $*$ & $0.28 \pm 0.052$ & $0.26 \pm 0.049$ & $\mathrm{NS}$ \\
\hline $\begin{array}{l}\text { Urea } \\
(\mathrm{mmol} / \mathrm{L}))\end{array}$ & $5.19 \pm 1.3$ & $4.8 \pm 1.06$ & $\mathrm{NS}$ & $4.8 \pm 1.06$ & $5.6 \pm 5.3$ & $\mathrm{NS}$ \\
\hline $\begin{array}{l}\text { Creatinine } \\
(\mu \mathrm{mol} / \mathrm{L})\end{array}$ & $65.9 \pm 16.9$ & $71.55 \pm 18.8$ & $\mathrm{NS}$ & $71.55 \pm 18.8$ & $79.13 \pm 22.8$ & $\mathrm{NS}$ \\
\hline $\begin{array}{l}\text { Urea:creatinine } \\
\text { ratio }\end{array}$ & $82.21 \pm 12.7$ & $70.08 \pm 17.28$ & $\mathrm{NS}$ & $70.08 \pm 17.2$ & $75.48 \pm 22.8$ & $\mathrm{NS}$ \\
\hline $\begin{array}{l}\text { Total cholesterol } \\
(\mathrm{mmol} / \mathrm{L})\end{array}$ & $5.15 \pm 0.49$ & $5.68 \pm 0.81$ & $*$ & $5.68 \pm 0.81$ & $5.3 \pm 0.14$ & NS \\
\hline $\begin{array}{l}\text { HDL-C } \\
(\mathrm{mmol} / \mathrm{L})\end{array}$ & $1.7 \pm 0.31$ & $1.52 \pm 0.27$ & $\mathrm{NS}$ & $1.52 \pm 0.27$ & $1.72 \pm 0.014$ & $\mathrm{NS}$ \\
\hline $\begin{array}{l}\text { Zinc } \\
(\mu \mathrm{mol} / \mathrm{L})\end{array}$ & $16.09 \pm 4.57$ & $12.45 \pm 4.39$ & $*$ & $12.45 \pm 4.39$ & $12.77 \pm 4.48$ & $\mathrm{NS}$ \\
\hline $\begin{array}{l}\text { Copper } \\
(\mu \mathrm{mo} / \mathrm{L})\end{array}$ & $15.56 \pm 4.49$ & $16.5 \pm 4.49$ & $\mathrm{NS}$ & $16.5 \pm 4.49$ & $18.05 \pm 7.6$ & $\mathrm{NS}$ \\
\hline
\end{tabular}

NS (not significant), *significant difference ( $\mathrm{P}$ value $\leq 0.05$ )

if the range of urea :creatinine ratio $=40-100$, this mean there is no renal injury. 
Table 3 : Some urinary biochemical measurements in healthy control(group A), calcium oxalate stone formers(group B)and calcium oxalate stone formers group (C) represented as mean+SD

\begin{tabular}{|c|c|c|c|c|c|c|}
\hline $\begin{array}{l}\text { Biochemical } \\
\text { Parameters } \\
\text { Measured in } \\
\text { Urine }\end{array}$ & $\begin{array}{c}\text { Group A } \\
(\mathrm{n}=29)\end{array}$ & $\begin{array}{c}\text { Group B } \\
(\mathrm{n}=16)\end{array}$ & $\begin{array}{c}p- \\
\text { value }\end{array}$ & $\begin{array}{c}\text { Group B } \\
(n=16)\end{array}$ & $\begin{array}{c}\text { Group C } \\
(n=15)\end{array}$ & $\begin{array}{c}p- \\
\text { value }\end{array}$ \\
\hline $\begin{array}{l}\text { urine volume } \\
(\mathrm{ml})\end{array}$ & $1765.2+551$ & $2003+507.7$ & NS & $2003+507.7$ & $1529 \pm 408.5$ & $\begin{array}{c}* \\
0.015\end{array}$ \\
\hline Urine $\mathrm{PH}$ & $5.4 \pm 0.24$ & $4.4+0.37$ & NS & $4.4 \pm 0.37$ & $5.2 \pm 0.8$ & NS \\
\hline Specific gravity & $1.026 \pm 0.004$ & $1.025 \pm 0.005$ & NS & $1.025 \pm 0.005$ & $1.022 \pm 0.007$ & NS \\
\hline $\begin{array}{l}\mathrm{Cr} . \mathrm{Cl} \\
\left(\mathrm{ml} / \mathrm{sec} / \mathrm{m}^{2}\right)\end{array}$ & $1.09 \pm 0.11$ & $1.13 \pm 0.3$ & NS & $1.13 \pm 0.3$ & $1.06 \pm 0.2$ & $\mathrm{NS}$ \\
\hline $\begin{array}{l}\text { Calcium } \\
(\mathrm{mmol} / 24 \mathrm{~h})\end{array}$ & $5.14 \pm 0.64$ & $6.61 \pm 1.13$ & $\begin{array}{c}* \\
0.05\end{array}$ & $6.61 \pm 1.13$ & $7 \pm 1.28$ & NS \\
\hline Urine $\mathrm{Ca}: \mathrm{Cr}$ & $0.17 \pm 0.016$ & $0.2 \pm 0.05$ & $\stackrel{*}{*}$ & $0.2 \pm 0.05$ & $0.2 \pm 0.13$ & NS \\
\hline $\begin{array}{l}\text { phosphate } \\
(\mathrm{mmol} / 24 \mathrm{~h})\end{array}$ & $24.08 \pm 8.8$ & $24.45+4.58$ & NS & $24.45+4.58$ & $27.84 \pm 7.29$ & NS \\
\hline $\begin{array}{l}\text { Uric acid } \\
(\mathrm{mmol} / 24 \mathrm{~h})\end{array}$ & $3.21 \pm 1.29$ & $3.49 \pm 0.9$ & NS & $3.49 \pm 0.9$ & $3.19 \pm 1.43$ & NS \\
\hline $\begin{array}{l}\text { Zinc } \\
(\mu \mathrm{mo} / 24 \mathrm{~h})\end{array}$ & $2.75 \pm 0.38$ & $2.86 \pm 0.3$ & NS & $2.86 \pm 0.3$ & $2.84 \pm 0.3$ & NS \\
\hline $\begin{array}{l}\text { Copper } \\
(\mu \mathrm{mol} / 24 \mathrm{~h})\end{array}$ & $0.376 \pm 0.05$ & $0.376 \pm 0.064$ & NS & $0.376 \pm 0.064$ & $0.34 \pm 0.042$ & NS \\
\hline
\end{tabular}

Calcium oxalate stone formers when compared with healthy control showed a significant decrease in serum uric acid and serum zinc levels while showed a significant increase in serum total cholesterol with $(p<0.05)$ (table $2)$, while other serum measurements showed no significant differences (table 2). Meanwhile,24-hours urine parameters showed no significant difference except for 24-hours urine calcium and urine calcium: creatinine ratio which was significantly higher in group B(stone formers) when compared to group A(healthy control) with ( $p \leq 0.05$ ) (table 3). However, comparison of different age groups of stone formers (between group B and group $\mathrm{C}$ ) group $\mathrm{C}$ showed lower urine volume than group $\mathrm{B}$, but other biochemical parameters exhibited no significant differences (table 3 ).

\section{Discussion}

The selected individuals were not on any type of vitamin or minerals and apparently to be of no significant differences in consuming red meat and carbonated or soda beverages, which have been reported to exert their effects by changing urinary parameters $^{(13,14)}$ especially calcium, phosphate, uric acid and urinary $\mathrm{PH}$ (table 1).

Concerning biochemical parameters measured in serum, phosphate level showed no significant difference between healthy individuals and calcium oxalate stone formers(table 2), this result was not 
agree with Polo et al study $^{15}$, may be because Polo's study incorporated patients with sever lithogenic activity and high recurrence rate with renal stone size more than $3 \mathrm{~cm}^{3}$.

The present study also showed a significant decrease in serum uric acid in calcium oxalate stone formers, group B when compared to healthy control $(p=0.015)$ (table 2), this decrease has been observed by Scholz et al study ${ }^{16}$ and Gyawali et al study ${ }^{17}$ which may be related to a decrease in antioxidant activity in stone formers. ${ }^{18}$ However, Gyawali et al study explained the result by multifactorial etiology of urinary stone and some genetic variation in Nepalese patients. $^{17}$

Calcium oxalate stone formers group B showed a significant increase in total serum cholesterol level but there is no significant changes in HDL$C$ level when compared to healthy control group $\mathrm{A}(P=0.034)$ (table2). This result is not in agreement with Polo et al study ${ }^{15}$ who found no significant changes in total serum cholesterol and HDL-C. However, it has been proposed that lipid play a significant role in calcium oxalate growth and the presence of high lipids in membrane of tubular cells provides a site for initial nucleation events ${ }^{19}$, because the free radicals generated from lipid peroxidation would facilitated the fixation of calcium oxalate crystals. ${ }^{20}$ New evidence suggested that nephrolithiasis and atherosclerosis shared common systemic risk factors and/or pathophysiology. ${ }^{21}$ Therefore, there is a low incidence of renal stone in Eskimos and Japaness due to increase in consumption of polyunsaturated fatty acids (like omega-3) which have reported effects in enhancing lipid status. ${ }^{22}$ Also, it was found that serum cholesterol was significantly increased in calculogenic rats and administration of $\alpha$-lipoic acid to rats counter act calcium oxalate crystallization, in addition to antilipemic activity. ${ }^{23}$

The lower value of serum zinc in stone formers when compared to healthy control $(p \leq 0.031)$ (table2) is in agreement with Atakan et al study ${ }^{24}$ as well as Ranqnekar and Gaur study ${ }^{25}$, that may be attributed to higher oxidative properties which lead to decrease antioxidant status in calcium oxalate stone formers ${ }^{18}$ as zinc is considered as a potent antioxidant. ${ }^{26}$

In accordance of urinary biochemical parameters measured in this study, there was no significant difference in 24-hours urine phosphate levels (table3),this result is not in agreement with Wikstrom et al study ${ }^{27}$ who suggested a decrease in renal phosphate handling in calcium stone formers. However, Wikstrom may incorporated in his study patients with larger stone size especially that, in the present study, phosphaturia was developed in one patient in group $\mathrm{C}$ his stone size was $10 \mathrm{~mm}^{3}$.

There was no significant differences in the levels of 24-hours urine uric acid (table 3), that agrees with Gurhan and Taylor study ${ }^{28}$ who incorporated 3350 renal stone formers, challenging the prevailing belief of that uric acid in urine increases the risk of calcium oxalate stone formation. ${ }^{29}$ However, the protective action of (Allopurinol) ${ }^{\circledR}$ to calcium oxalate stone may be related to improve endothelial dysfunction and reducing oxidative stress. ${ }^{30,31}$.

Also there was a significant increase in 24-hours urine calcium in calcium oxalate stone formers when compared to healthy control $(p=0.05)$ (table3), which is in agreement with Polo et al study ${ }^{15}$ who measured 24hour urine calcium in general calcium stone formers with sever lithogenic activity and found a significant hypercalciuria in stone formers with $(p=0.000)$. However, Conte et $\mathrm{al}^{32}$ study explained that, calcium 
oxalate stone is more frequent in normocalciuric patients, while mixed calculus of calcium oxalate and phosphate associated with marked hypercalciuria. Moreover, this study showed a significant increase in urine calcium: creatinine ratio in calcium oxalate stone formers when compared to controls (table3), indicating that there is higher calcium leak from kidneys of stone formers than kidneys of control, which may attributed to the presence of interstitial papillary deposits that may affect on calcium reabsorption. ${ }^{33}$

This study also exhibited no differences in urinary zinc between different groups (table3), which is in contrast with Atakan et al study ${ }^{24}$ who found a higher urinary zinc in healthy individuals while Ranqnekar and Gaur study $^{25}$ as well as Ozgurtas et al study $^{34}$ found a higher urinary zinc in stone formers, suggesting that urinary zinc possess no inhibitory activity to calcium oxalate stone formation. Also this study exhibited no differences in serum and urine copper (table2, table 3 ) that agrees with Ozgurtas et al study ${ }^{34}$ suggesting that there is no effect of urinary copper on formation of kidney stone.

Lastly, concerning urine volume, the lower urine volume in older age group calcium oxalate stone formers when compared to younger age group calcium oxalate stone formers (group C and group B) $(p \leq 0.015) \quad($ table 3$)$ may be attributed to a lesser consumption of water. However, the lower urine volume can increase concentration of lithogenic substances in urine ${ }^{35}$ and may result in significant increase in stone size of this group of stone formers (group $C$ ) when compared to (group B) $(p \leq 0.03)$ (table $1)$.

In conclusion: level of urinary calcium and urine volume are the most important urinary factors in enhancing calcium oxalate stone formation. While the observed changes in biochemical measurements of serum in calcium oxalate stone formers may indicate a probable metabolic relation in pathogenesis of this disease.

\section{References}

1- Knoll T.Epidemiology, pathogenesis and pathophysiology of urilithiasis. European Urology Supplements 2010;9:802-806.

2-Chen YK, Lin HC,Chen CS, et al.Seasonal variations in urinary calculi attacks and their association with climate: a population based study. J Urol 2008;179:564-569.

3- Moe O W .Kidney stones: pathophysiology and medical management. The Lancet 2006;367:333-334.

4- Trinchieri A. Epidemiology of urilthiasis :an update. Clin Cases Miner Bone Metab 2008;5:101106.

5- Pack C Y C, Huet B A, Poindexter J $\mathrm{R}$, et al. Relative effect of urinary calcium and oxalate on saturation of calcium oxalate. Rapid Communication. Kidney International 20322037.

6- Maghbooli Zn, Hossein -Nezhad A, Adibi $\mathrm{H}$, et al. Association between Renal stone ,Bone Mineral Density and Biochemical Parameters. Iranian J Publ Health 2007:45-50.

7-Mossetti G, Rendina D, Filippo G, et al. Metabolic syndrome and nephrolithiasis : can we hypnotize a common background?. Clin Cases Miner Bone Metab 2008;5:114-117.

8- Daudon M, Donsimoni R, Hennequin C, et al. Sex and age related composition of 10617 calculi analysed by infrared spectroscopy. Urol Res 1995;23:319-326. 
9-Qaader DS, Yousif SY, Mahdi LK. Prevalence and etiology of urinary stones in hospitilazied patients in Baghdad. East Mediterr Health J 2006;12:853-856.

10-Bushinsky D A.Recurrent hypercalciuric nephrolithiasisDoes diet help?. New England Journal of Medicine 2002;346:124-125.

11- Daudon M, Jungers P. Clinical Value of Crystalluria and Quantitative Morphoconstitutional Analysis of Urinary Calculi. Nephron Physiol 2004;98:31-36.

12- Kaid-Omar Z, Daudon M, Attar A, et al. Correlations between crystalluria and composition of calculi. Prog Urol 1999;9Sep.:633-641.

13- Weiss GH, Sluss PM, Linke CA. Changes in urinary magnesium, citrate and oxalate levels due to cola consumption. Urology 1992;39:331-333.

14- Hesse A, Siener R, Heynck H, et al. The influence of dietary factors on the risk of urinary stone formation. Scanning Microsc 1993;7:1119-1127.

15- Polo M A, Martin M A, HaroMuñoz $\mathrm{T}$, et al. Biochemical Determinants of sever lithogenic Activity in patients with idiopathic calcium Nephrolithiasis. Endourology and Stone 2012;79: 48-54.

16- Scholz D, Schwille PO, Ulbrich D, et al. Composition of renal stones and their frequency in stone clinic: relationship to parameters of mineral metabolism in serum and urine. Urol Res 1979 ;7:161-170.

17-Gyawali PR, Joshi BR, Gurung CK. Correlation of calcium ,phosphorus ,uric acid a magnesium level in serum and 24 hours of patients with urolithiasis. Kathmanda Univ Med J 2011;34:54-56.
18 -Thamilselvan S, Khan S R, Menon M. Oxalate and calcium oxalate mediated free radical toxicity in renal epithelial cells:effect of antioxidant.Urol Res2003;31:3-9.

19- Talham D R, Backov R, Benitez I $\mathrm{O}$, et al. Role of lipids in urinary stones:studies of calcium oxalate precipitation at phospholipid Langmuir monolayers. Langmuir 2006;22:2450-2456.

20-Selvam R. Calcium oxalate stone disease .role of lipid peroxidation an antioxidant. Urol Res 2002;30:35-47.

21- Alexander P, Kahn A, Elsner B H, et al. Kidney stones and subclinical Atherosclerosis in young adults:The CARDIA study. The Journal of Urology 2011;185: 920-925.

22- Baggio B. Genetic and dietary factors in idiopathic calcium nephrolithiasis: what do we have , what do we need?. J Nephrol 1999;12:371-374.

23- Sumathi R, Jayanthi S, Uaralakshmi P. Impaired lipid metabolism in calcium -oxalate stone forming rat and DL alphalipoic acid supplementation. Nutr Res 1995;15:59-70.

24- Atakan I H, Kaplan M, Seven G, et al. Serum ,Urinary and stone zinc, iron, magnesium and copper levels in idiopathic calcium oxalate stone patients. International Urology and Nephrology 2007;39:351-356.

25- Ranqnekar GV, Gaur MS. Serum and urinary zinc levels in urolithiasis. $\mathrm{Br} \quad \mathrm{J} \quad$ Urol 1993;71:527-529.

26- Powell S R. The Antioxidant Properties of Zinc. Journal of Nutrition 2000; 130:1447-1454.

27- Wikström B, Backman U, Danielson BG, et al. Phosphate metabolism in renal stone formers.(П): Relation to renal tubular function and calcium 
metabolism .Scand J Urol Nephrol 1981;61:1-26.

28- Curhan GC and Taylor EN. $24-\mathrm{hr}$ uric acid excretion and th risk of kidney stones. Kidney Internatinal 2008;73:489-496.

29-Ettinger B. Does hyperuricosuria play a role in calcium oxalate lithiasis ?. J Urol 1989;141:738741.

30- Guthikonda S, Sinkey C, Barenz T, et al. Xanthine oxidase inhibition reverses endothelial dysfunction in heavey smokers. Circulation 2003;107:416-421.

31- Farquharson C A, Bulter R, Hill A, et al. Allopurinol improves endothelial dysfunction in chronic heart failure. Circulation. 2002; 106:221-226.

32- Gonte A, Genestar C, Grases F. Relation between calcium oxalate hydrate form in renal calculi and some urinary parameters. Urol Int 1990;45:25-27.

33- Kuo RL, Lingeman JE, Evan AP, et al. Urine calcium and volume predict coverage of renal papilla by Randall's plaque. Kidney International 2003; 64: 21502154.

34-Ozgurtas T, Yaku G, Gulec M, et al. Role of urinary zinc and copper on calcium oxalate stone formation. Urol Int 2004;72:233236.

35-Goldfarb S. The role of diet in the pathogenesis and therapy of nephrolithiasis. Endo Metab Clin North Am 1990;19:805-820. 